\title{
A COMPARATIVE STUDY OF DISABILITY AND ITS BURDEN ON FAMILY MEMBERS OF BIPOLAR AND UNIPOLAR DEPRESSION PATIENTS
}

\author{
Aftab Ahmed Khan1, Priyanka Chouhan², Rahila Qureshi ${ }^{3}$ \\ ${ }^{1}$ Assistant Professor, Department of Psychiatry, NSCB Medical College, Jabalpur, Madhya Pradesh. \\ 2Junior Resident, Department of Physiology, NSCB Medical College, Jabalpur, Madhya Pradesh. \\ 3Medical Officer, PH\&FW Department, Jabalpur, Madhya Pradesh.
}

\section{ABSTRACT}

\section{AIMS AND OBJECTIVE}

The primary purpose of this study is to compare the disability and its burden on the family members or caregivers of patients with bipolar and unipolar depression.

\section{METHODOLOGY}

The study was carried out in thirty cases of Bipolar and Unipolar depressive patients and their healthy relatives residing with the patient since last one year. Comparisons were made under various headings between Unipolar and Bipolar groups. Obtained Data were analysed by using unpaired ' $t$ ' test, Pearson's correlation coefficient and z-score.

\section{RESULTS}

On applying IDEAS (Indian Disability Evaluation Assessment Scale), the mean scores were very low in bipolar depressed patients in comparison to unipolar depressed patients for the self-care(1.33 and 0.57),interpersonal activities(1.83 and 1.13),communication and understanding(1.80 and 0.87),work(2.63 and 1.10) and global disability score(11.50 and 7.43) and were statistically significant $(\mathrm{p}<0.001)$.The family burden was 33.76 and 23.57 in Bipolar depression and Unipolar depression using Family Burden Interview scale and was statistically significant $(\mathrm{p}<0.001)$. No statistically significant correlation was found between socio-demographic factors, disability and family burden in both study and control group.

\section{CONCLUSION}

Bipolar depressive patients were significantly more disabled than patients with unipolar depression in all parameters of disability scale. Families of Bipolar depressive patients experienced significantly greater burden in comparison to families of patients with unipolar depression.

\section{KEYWORDS}

Bipolar Disorder, Disability, Burden.

HOW TO CITE THIS ARTICLE: Khan AA, Chouhan P, Qureshi R. A comparative study of disability and its burden on family members of bipolar and unipolar depression patients. J. Evolution Med. Dent. Sci. 2016;5(19):964-968,

DOI: $10.14260 /$ jemds/2016/224

\section{INTRODUCTION}

Bipolar disorder is an intermittent to chronic psychiatric disorder characterized by recurring episodes of severe depressive illness and at least one episode of mania or hypomania. [1] A major portion of the morbidity and mortality associated with bipolar disorder is derived from depressive episodes and symptoms rather than manic characteristics. Bipolar disorder is a substantial public health problem. Lifetime prevalence for the spectrum of bipolar illness is approximately $3.7 \%$. [2] with an average onset at age 20 and prevalence is highest in young adults.[3] In Indian studies prevalence of Bipolar affective patient is given as 0.7 to 2.7 per thousand.[4] Depression in Bipolar affective patient imposes a greater overall burden on patients and families as compared to unipolar depression.

Financial or Other, Competing Interest: None.

Submission 20-01-2016, Peer Review 16-02-2016,

Acceptance 22-02-2016, Published 07-03-2016.

Corresponding Author:

Dr. Aftab Ahmed Khan,

Assistant Professor,

Department of Psychiatry,

NSCB Medical College,

Jabalpur, Madhya Pradesh.

E-mail:draftab79@yahoo.com

DOI:10.14260/jemds/2016/224
The importance of mental illness as a cause of disability was realized when the Global Burden of Disease Project found out that mental illnesses accounted for a quarter of the world's disability.[5]Four of the 10 leading causes of disability worldwide are mental disorder viz. major depression, Alcohol use disorder, schizophrenia and in Bipolar affective patient.[6] Disability refers to the limitation in functioning that may take place at the following different levels of body, personality and society. The nature and extent of disability associated with a psychiatric illness could be an important marker of illness severity as dysfunction is a necessary criterion for the diagnosis of psychiatric disorder. Bipolar disorder has been found to be associated with the following types of disability: increased suicidal behaviour, increased health care use and cost, higher unemployment rate, higher dependence on public assistance, lower annual income and increased work absenteeism owing to illness, decreased work productivity, poor overall functioning and decreased life span. $[7,8]$

Bipolar disorder also imposes a greater overall burden on families as compared to unipolar depression. It may be due to an earlier age of onset, more frequent episodes, panic disorder between episodes, psychosis; than patients with pure manic episodes,[9] and a greater proportion of time spent in illness.[10] It affects the family members in terms of disruption in routine family activities, family leisure, family 
interaction, interference in their normal work, physical and mental health and entails an additional financial burden.

Chakrabarti, et al. (1992) found out that the objective burden on caregivers of hospitalized patients and outpatients with bipolar disorder was significantly higher than for those with unipolar depression.[11]

Surprisingly, in spite of being such an important illness, there has been very little empirical research done to assess the impact of bipolar depression on patients and their caregivers.

The primary purpose of this study is to examine the demographics and compare disability and its burden on the family of patients with bipolar and unipolar depression.

\section{METHODOLOGY}

In the present study, the psychosocial impact of bipolar depression on the patients and on their caregivers is measured and compared with the impact of unipolar depression on the depressed subjects and on their caregivers.

\section{AIMS AND OBJECTIVES}

1. To assess disability in patients with bipolar depression.

2. To study family burden on caregivers of patients with bipolar depression.

3. To compare disability and family burden on caregivers of patients with bipolar depression with the caregivers of unipolar depressed control.

\section{MATERIAL AND METHODS}

In this study, 30 consecutive demographically comparable patients of bipolar depression and 30 patients of unipolar depression diagnosed were taken with equal number of their caregivers. They were diagnosed as per ICD-10 criteria and attending OPD at psychiatric centre or psychiatric clinic at SMS medical college, hospital, Jaipur, India for treatment. A written informed consent was obtained from all the patients and their caregivers.

\section{Inclusion Criteria}

Patients between 18-60 years of age fulfilling the ICD-10 criteria for moderate or severe depressive disorders with minimum duration of illness being two years (score of $>16$ on Beck Depression Inventory). There should be at least one hypomanic, manic or mixed affective episode in the past. Caregivers must have stayed with the patients continuously for the last one year.

\section{Exclusion Criteria}

Illiterate, uncooperative patients and caregivers with any other comorbid major psychiatric disorder or any chronic physical illness, organic brain disorder or substance dependence were excluded from the study.

\section{Tools of Study}

A specially designed semi structured proforma was used for through evaluation of the patients and caregivers. It included the socio-demographic data and clinical profile sheet.

\section{Beck Depression Inventory (BDI)}

The BDI rates severity with focus on behavioural and cognitive dimensions of depression. It contains 21 items, scores 0 to 3 of which 15 items deal with psychological symptoms and six are concerned with somatic ones.
Indian Disability Evaluation Assessment Scale (IDEAS)

The rehabilitation committee of Indian Psychiatric Society developed this scale. It had been tested in various centres. The alpha value was 0.8682 indicating good internal consistency between the items. It has good criterion validity and at face values. The instrument measures the desired disability. [12]

\section{The Family Burden Interview Schedule (FBIS)}

This scale has been developed by Pai and Kapur. [13] It is a semi-structured interview schedule. It comprises of 24 items grouped under six areas which includes financial burden, disruption of routine family activities, family interaction and leisure, effect on physical and mental health of others. A single item as a global rating measures subjective burden.

\section{Data Analysis}

The statistical treatment of the data has been done by employing both nonparametric and parametric statistical measure. Non-parametric statistical measures include frequencies, percentages, whereas parametric statistical measures include unpaired t-test and z-test and Pearson's product moment correlation.

\section{RESULTS}

\begin{tabular}{|c|c|c|}
\hline Variable & $\begin{array}{c}\text { Bipolar } \\
\text { depression } \\
n=30, f(\%)\end{array}$ & $\begin{array}{c}\text { unipolar } \\
\text { depression } \\
n=30, \mathbf{f}(\%)\end{array}$ \\
\hline Age in (years)- mean(SD) & $31.90(7.16)$ & $36.30(11.23)$ \\
\hline $\begin{array}{l}\text { Sex } \\
\text { 1. Male } \\
\text { 2. Female }\end{array}$ & $\begin{array}{l}23(76.66) \\
7(23.34)\end{array}$ & $\begin{array}{l}24(80.0) \\
6(20.0)\end{array}$ \\
\hline Marital Status & & \\
\hline $\begin{array}{ll}\text { 1. } & \text { Single } \\
\text { 2. } & \text { Married } \\
\text { 3. } & \text { Remarried } \\
\text { 4. } & \text { Widowed } \\
\text { 5. } & \text { Divorced } \\
\text { 6. } & \text { Separated }\end{array}$ & $\begin{array}{l}14(28.0) \\
34(68.0) \\
- \\
2(4.0) \\
- \\
-\end{array}$ & $\begin{array}{l}10(21.3) \\
36(76.6) \\
- \\
- \\
- \\
1(2.1)\end{array}$ \\
\hline $\begin{array}{l}\text { Occupation } \\
\text { 1.Professional/Semiprof./ } \\
\text { Skilled Worker/ } \\
\text { 2.Farmer/Semi- } \\
\text { skilled/Labours } \\
\text { 3.Unemployed/ } \\
\text { Housewife/Student/ Retired }\end{array}$ & $\begin{array}{l}10(33.3) \\
10(33.3) \\
10(33.3)\end{array}$ & $\begin{array}{l}14(46.67) \\
7(23.33) \\
9(30.0)\end{array}$ \\
\hline $\begin{array}{ll}\text { Education } \\
\text { 1. } \\
\text { 2. } \text { Militerate } \\
\text { 3. } \text { Matric/ Inter } \\
\text { 4. } & \text { Graduate/Post Graduate }\end{array}$ & $\begin{array}{l}- \\
4(13.3) \\
23(76.67) \\
3(10.0)\end{array}$ & $\begin{array}{l}- \\
5(16.67) \\
11(26.67) \\
14(46.67)\end{array}$ \\
\hline $\begin{array}{l}\text { Monthly Income } \\
\text { 1. nil } \\
\text { 2. } \quad<3000 \\
\text { 3. }>3000\end{array}$ & $\begin{array}{l}19(63.33) \\
7(23.33) \\
4(13.33)\end{array}$ & $\begin{array}{l}6(20.0) \\
9(30.0) \\
15(50.0)\end{array}$ \\
\hline \begin{tabular}{ll}
\multicolumn{2}{l}{ Religion } \\
1. & Hindu \\
2. & Muslim \\
3. & Sikh \\
4. & Christian
\end{tabular} & $\begin{array}{l}27(90.0) \\
3(10.0) \\
- \\
-\end{array}$ & $\begin{array}{l}30(100) \\
- \\
- \\
-\end{array}$ \\
\hline \begin{tabular}{l}
\multicolumn{2}{l}{ Family type } \\
1. Nuclear \\
2. $\quad$ Joint/Others \\
\end{tabular} & $\begin{array}{l}20(66.64) \\
10(33.34) \\
\end{array}$ & $\begin{array}{l}18(60.0) \\
12(40.0) \\
\end{array}$ \\
\hline $\begin{array}{l}\text { Locality } \\
\text { 1. Urban } \\
\text { 2. } \text { Rural }\end{array}$ & $\begin{array}{l}19(63.34) \\
11(37.66)\end{array}$ & $\begin{array}{l}26(86.67) \\
4(13.33)\end{array}$ \\
\hline
\end{tabular}




\begin{tabular}{|c|c|c|c|c|c|}
\hline \multirow{2}{*}{ Parameter } & \multicolumn{2}{|c|}{ Group } & \multicolumn{2}{|c|}{ P-value } & \multirow{2}{*}{ Significance } \\
\cline { 2 - 5 } & Control & Case & & $<.001$ & HS \\
\hline \multirow{2}{*}{ BDI } & Male & $26.42+6.62$ & $36.85+5.22$ & $<.001$ & HS \\
\cline { 2 - 5 } & Female & $20.00+3.91$ & $36.85+5.22$ & $<.001$ & HS \\
\hline \multirow{2}{*}{ Burden } & Male & $23.96+3.28$ & $34.17+3.95$ & $<.001$ & HS \\
\cline { 2 - 6 } & Female & $22.00+1.73$ & $32.43+3.69$ & $<.001$ & HS \\
\hline \multirow{2}{*}{$\begin{array}{c}\text { Disability } \\
\text { Score }\end{array}$} & Male & $7.79+1.66$ & $11.43+1.43$ & $<.001$ & HS \\
\cline { 2 - 6 } & Female & $6.00+1.15$ & $11.71+1.48$ & & \\
\hline
\end{tabular}

Table 2: Group comparisons of Socio-demographic Profiles between Bipolar Depression and Unipolar Depression Group

\begin{tabular}{|c|c|c|c|c|}
\hline Variable & $\begin{array}{c}\text { Bipolar Depression } \\
(\mathbf{n = 3 0 )} \text { mean (SD) }\end{array}$ & $\begin{array}{c}\text { Unipolar Depression } \\
(\mathbf{n}=\mathbf{3 0}) \text { mean (SD) }\end{array}$ & P-Value & Significance \\
\hline Total BDI score & $35.67(5.83)$ & $25.13(6.80)$ & $<.001$ & HS \\
\hline \multicolumn{4}{|c|}{ Table 3: Distribution and Comparison of Severity of Depressive } \\
Symptoms in Bipolar Depression and Unipolar Depression Group \\
\hline
\end{tabular}

\begin{tabular}{|l|c|c|c|}
\hline \multicolumn{1}{|c|}{ Variable } & $\begin{array}{c}\text { Bipolar Depression } \\
(\mathbf{n = 3 0 )} \text { mean (SD) }\end{array}$ & $\begin{array}{c}\text { Unipolar Depression } \\
(\mathbf{n = 3 0} \text { mean (SD) }\end{array}$ & P-value \\
\hline Duration of illness & & & $>.05$ \\
1. 2-5 years & $8(26.67)$ & $19(63.34)$ & $<.01$ \\
2. >5 years & $22(73.33)$ & $11(36.66)$ & $<.01$ \\
\hline Family History of Psychiatric Illness & $11(36.67)$ & $2(6.67)$ & $>.05$ \\
1. Present & $19(63.33)$ & $28(93.33)$ & \\
2. Absent & \multicolumn{2}{|c|}{ Table 4: Comparison of Clinical Characteristics between Bipolar Depression and Unipolar Depression Group }
\end{tabular}

\begin{tabular}{|c|c|c|c|c|}
\hline $\begin{array}{c}\text { Variable } \\
\text { (IDEAS) }\end{array}$ & $\begin{array}{c}\text { Bipolar Depression } \\
\text { (n= 30) mean (SD) }\end{array}$ & $\begin{array}{c}\text { Unipolar Depression(n=30) } \\
\text { mean (SD) }\end{array}$ & P-Value & Significance \\
\hline Self-Care & $1.33(0.48)$ & $0.57(0.50)$ & $<.01$ & Sig \\
\hline $\begin{array}{c}\text { Interpersonal } \\
\text { Activities }\end{array}$ & $1.83(0.46)$ & $1.13(0.78)$ & $<.001$ & $\mathrm{HS}$ \\
\hline $\begin{array}{c}\text { Communication \& } \\
\text { Understanding }\end{array}$ & $1.80(0.66)$ & $0.87(0.51)$ & $<.001$ & $\mathrm{HS}$ \\
\hline Work & $2.63(.61)$ & $1.10(0.61)$ & $<.001$ & $\mathrm{HS}$ \\
\hline Global Disability Score & $11.50(1.45)$ & $7.43(1.73)$ & $<.001$ & $\mathrm{HS}$ \\
\hline \multicolumn{2}{|l}{} \\
\multicolumn{2}{|l}{} \\
\hline
\end{tabular}

\begin{tabular}{|c|c|c|c|c|}
\hline Variable & $\begin{array}{c}\text { Bipolar Depression } \\
(\mathbf{n = 3 0} \text { mean (SD) }\end{array}$ & $\begin{array}{c}\text { Unipolar Depression } \\
(\mathbf{n}=30) \text { mean (SD) }\end{array}$ & P-Value & Significance \\
\hline Family Burden & $33.76(3.96)$ & $23.57(3.14)$ & $<.001$ & HS \\
\hline \multicolumn{2}{|c|}{ Table 6: Comparison of Family burden Score in Bipolar Depression and Unipolar Depression Group } \\
\hline
\end{tabular}

\begin{tabular}{|c|c|c|c|c|c|c|}
\hline Variable & & Self-Care & Inter-personal Relationship & $\begin{array}{c}\text { Communication \& Under } \\
\text { standing }\end{array}$ & Work & $\begin{array}{c}\text { Global } \\
\text { Disability } \\
\text { Score }\end{array}$ \\
\hline \multirow{2}{*}{$\begin{array}{l}\text { Age in } \\
\text { (years) }\end{array}$} & $\mathrm{BD}$ & .060 & .245 & .155 & .046 & .151 \\
\hline & UD & .255 & -.044 & .207 & .475 & .332 \\
\hline \multirow{2}{*}{ Sex } & $\mathrm{BD}$ & -.056 & .203 & .290 & -.187 & .081 \\
\hline & UD & -.404 & -.415 & -.200 & -.084 & -.415 \\
\hline \multirow{2}{*}{$\begin{array}{l}\text { Marital } \\
\text { Status }\end{array}$} & $\mathrm{BD}$ & -.000 & .180 & .438 & -.135 & .084 \\
\hline & UD & .157 & .058 & .134 & .056 & .277 \\
\hline \multirow{2}{*}{ Occupation } & $\mathrm{BD}$ & -.156 & -.020 & -.124 & -.058 & -.120 \\
\hline & UD & -.151 & -.116 & .079 & -.080 & -.184 \\
\hline \multirow{2}{*}{ Education } & $\mathrm{BD}$ & .084 & -.350 & -.036 & -.039 & -.109 \\
\hline & UD & -.440 & -.473 & -.235 & .084 & -.311 \\
\hline \multirow{2}{*}{$\begin{array}{l}\text { Monthly } \\
\text { income }\end{array}$} & $\mathrm{BD}$ & .249 & -.259 & -.099 & -.058 & -.081 \\
\hline & UD & -.231 & -.270 & -.216 & .154 & -.142 \\
\hline \multirow{2}{*}{ Religion } & $\mathrm{BD}$ & .000 & -.123 & -.068 & -.165 & -.115 \\
\hline & UD & - & - & - & - & - \\
\hline \multirow{2}{*}{$\begin{array}{l}\text { Family } \\
\text { type }\end{array}$} & $\mathrm{BD}$ & -.200 & -.052 & -.000 & .195 & .000 \\
\hline & UD & .279 & .450 & .116 & .045 & .385 \\
\hline \multirow{2}{*}{ Locality } & $\mathrm{BD}$ & .049 & -.331 & -.402 & .233 & -.166 \\
\hline & UD & .049 & -.331 & $-.402^{*}$ & .233 & -.166 \\
\hline
\end{tabular}

Table 7: Correlation between Disability and Sociodemographic Characteristics in Patients with Bipolar Depression \& Unipolar Depression ${ }^{*} \mathrm{p}<.05,{ }^{* *} \mathrm{p}<.01$, Pearson product moment $(\mathrm{r})$, 


\begin{tabular}{|c|c|c|c|c|c|c|}
\hline Variable & & Self-Care & $\begin{array}{c}\text { Inter-personal } \\
\text { Relationship }\end{array}$ & $\begin{array}{c}\text { Communication \& } \\
\text { Understanding }\end{array}$ & Work & $\begin{array}{c}\text { Global } \\
\text { Disability Score }\end{array}$ \\
\hline \multirow{2}{*}{$\begin{array}{c}\text { Duration of illness } \\
\text { Eamily History of psychiatric } \\
\text { illness }\end{array}$} & BD & .107 & .111 & $.392^{*}$ & .008 & -.013 \\
\cline { 2 - 7 } & BD & .107 & -.042 & -.074 & -.127 & .049 \\
\cline { 2 - 7 } & UD & -.234 & .178 & $.508^{*}$ & .111 & $.404^{*}$ \\
\hline \\
Table 8: Correlation between Disability and Clinical Characteristics \\
in Patients with Bipolar Depression \& Unipolar Depression \\
\hline
\end{tabular}

${ }^{*} \mathrm{p}<.05,{ }^{* *} \mathrm{p}<.01$, Pearson product moment $(\mathrm{r})$

\begin{tabular}{|c|c|c|c|c|c|c|}
\hline $\begin{array}{c}\text { Variable } \\
\text { (BDI) }\end{array}$ & Self-Care & $\begin{array}{c}\text { Interpersonal } \\
\text { Relationship }\end{array}$ & $\begin{array}{c}\text { Communication \& } \\
\text { Under-standing }\end{array}$ & Work & $\begin{array}{c}\text { Global Disability } \\
\text { Score }\end{array}$ \\
\hline \multirow{2}{*}{ Total score } & BD & .411 & .325 & $.481^{* *}$ & .292 & $.595^{* *}$ \\
\cline { 2 - 6 } & UD & $.701^{* *}$ & $.676^{* *}$ & $.365^{*}$ & .297 & $.714^{* *}$ \\
\hline \multicolumn{7}{|r|}{ Table 9: Correlation between Disability and Severity of Depression } \\
in Patients with BipolarDdepression and Unipolar Depression Group \\
\hline
\end{tabular}

Pearson product moment(r), ${ }^{*} \mathrm{p}<.05,{ }^{* *} \mathrm{p}<.01$

\begin{tabular}{|c|c|c|}
\hline $\begin{array}{c}\text { Variable } \\
\text { (BDI) }\end{array}$ & \multicolumn{2}{|c|}{ Family Burden } \\
\hline \multirow{2}{*}{ Total Score } & BD & $.406^{*}$ \\
\cline { 2 - 3 } & UD & $.406^{*}$ \\
\hline Table 10: Correlations of Severity of Depression with \\
Family Burden in Patients with Bipolar Depression and \\
Unipolar Depression Group
\end{tabular}

Pearson product moment(r), ${ }^{*} \mathrm{p}<.05,{ }^{* *} \mathrm{p}<.01$

\begin{tabular}{|c|c|}
\hline Variable & Family Burden \\
\hline Duration of Illness & .155 \\
\hline $\begin{array}{c}\text { Family history of psychiatric } \\
\text { illness }\end{array}$ & .130 \\
\hline \multicolumn{2}{|c|}{$\begin{array}{c}\text { Table 11: Correlation between Family burden and } \\
\text { Clinical Characteristics in Patients with Bipolar } \\
\text { Depression and Unipolar Depression Group }\end{array}$} \\
\hline
\end{tabular}

${ }^{*} \mathrm{p}<.05,{ }^{* *} \mathrm{p}<.01$, Pearson product moment $(\mathrm{r})$

\begin{tabular}{|c|c|c|c|c|c|c|}
\hline Variable & & $\begin{array}{c}\text { Self- } \\
\text { Care }\end{array}$ & $\begin{array}{c}\text { Inter- } \\
\text { personal } \\
\text { Relation- } \\
\text { ship }\end{array}$ & $\begin{array}{c}\text { Commun } \\
\text { ication\& } \\
\text { Under- } \\
\text { standing }\end{array}$ & Work & $\begin{array}{c}\text { Global } \\
\text { Disability } \\
\text { Score }\end{array}$ \\
\hline $\begin{array}{c}\text { Family } \\
\text { Burden }\end{array}$ & BD & .345 & .015 & .136 & .136 & .251 \\
\hline & UD & $.501^{* *}$ & $.525^{* *}$ & .197 & .183 & $.527^{* *}$ \\
\hline \multicolumn{7}{r|}{ Table 12: Correlations of Family burden with Disability in Patients with }
\end{tabular}

Table 12: Correlations of Family burden with Disability in Patients with

Bipolar Depression and Unipolar Depression Group

\section{DISCUSSION}

The mean age of bipolar depressive subjects was 31.90 $(\mathrm{SD}=7.16)$ and that of depressed was 36.60 (SD=11.23). The bipolar depressive sample was younger in comparison to other studies in this area.[14,15] Most of the respondents included in our study were married males, belonging to Hindu religion, nuclear families and from urban background. Estimate of unemployment in Bipolar depressive group is reported to be $33.3 \%$, which is also seen in earlier studies [10].Most of the patients in Bipolar depressive group were educated up to metric or Inter level (76.67\%) while in Unipolar depressive group patients were mostly Graduate or Post Graduate (46.67\%). This is also a reason for lower income (Nil 63.33\%) in bipolar depressive patients because majority of the bipolar depressive patients had education levels below graduation, which probably led them to accept low paying jobs. It is also possible that bipolar depression (inclusion criteria of illness duration $>2$ years) is a more disabling illness, thus hampering the educational attainment and occupation functioning as shown in an earlier study by Judd LL, et al.[16,17]

Comparison of clinical characteristics between bipolar depression and unipolar depression groups showed significant differences in the duration of illness. [Duration more than 5 years in Bipolar group is $73.33 \%$, while in Unipolar group is $36.66 \%$ (p value<.01)]. This may be because unipolar depression usually responds better to the treatment.[18] The bipolar depression seems to be more chronic than unipolar depression in our study, which corresponds to the findings in other studies.[14,16,19]Bipolar depressive patients have been found to have statistically significant higher score on all parameters of disability scale, which indicates that bipolar depressive patients were more disabled than the unipolar depressed.

The difference in the score could be due to the severity of depression in the two samples (p-value<.001). Bipolar patients, however, were disabled maximally in the work domain (2.63 \pm 67) which assesses the Pearson's performance in work/jobs, in house work and in school/college.

This may be due to the fact that most of the patients in bipolar depressive group had no source of income $(63.3 \%)$ in comparison to unipolar depressive group (20.0\%). The bipolar depressive patients also had statistically significant low score on self-care, interpersonal activities, communication and understanding in comparison to unipolar depressed subjects. The overall disability in study group was also statistically significantly low from that of the control group(p-value<.001). It is possible that since bipolar depressed patients had been ill for longer duration $(>5$ years $=73.33 \%$ ), family members must have felt the impact of bipolar depressed patients' disabilities more because of the acuteness and severity of depressive symptoms. These findings are consistent with the result of other studies. [20, 21]

The evaluation of burden on the caregivers was done as one of the means to assess the impact of bipolar depression on the caregivers. The information regarding the burden is obtained from the relative who were providing care for the patient for at least one year. The family burden Interview schedule is used to measure the burden in six different areas like financial burden, disruption of routine family activities, disruption of family leisure and family interaction, effect on physical health of others and effect on mental health of others. Burden was found to be present in all the areas. 
The total score of family burden in study group is statistically significant with higher score in comparison to unipolar depression group(p-value<.001).

This may be due to more duration of illness, frequent hospitalizations, most of the patients having no source of income and more severe depression in study group.

These findings are consistent with other comparative studies.[22,23,24,25]The mean score of the Bipolar depressed group was 35.67 (SD 5.83), which lies in the severe range. Unipolar depressive subjects had a mean score of 25.13 (SD 6.80), which also falls in severe ranges but less severe significantly than bipolar depressive patients.

Correlation between parameters of impact of bipolar depression and socio-demographic/clinical/psychological variables-No statistically significant correlation was found between Socio-demographic factors, disability and family burden in both study and control group. This may be due to small sample size $(\mathrm{N}=30)$ in both study and control group. Family history of psychiatric illness had also significant positive correlation with Global disability score. These finding shows that presence of family history of psychiatric illness correlated positively with overall disability. Severity of depression is statistically significant positively correlated with Global disability score, which shows that with increase in severity of depression, disability also increase. There is significant positive correlation between severities of depression with family burden. This indicates that family burden increases when patient's depressive symptoms increases.

\section{SUMMARY AND CONCLUSIONS}

Bipolar depressive patients were significantly more disabled than patients with unipolar depression in all parameters of disability scale. Families of bipolar depressive patients experienced significantly greater burden in comparison to families of patients with unipolar depression.

\section{REFERENCES}

1. American psychiatric association. Diagnostic and statistical manual of mental disorder, Text revision. Washington DC: American psychiatric association, 2000; $4^{\text {th }}$ Edition.

2. Akiskal HS, Bourgeois ML, Angst J. Re-evaluating the prevalence of and diagnostic composition within the broad clinical spectrum of bipolar disorders. J Affect Disorder 2000;59(suppl):S5-S30.

3. Hirschfeld RM, Calabrese JR, Weissman MM. Screening for bipolar disorder in community. J Clin Psychiatry 2003;64:53-59.

4. Reddy MV, Chandrashekar CR. Prevalence of mental and behavioural disorder in India: a meta-analysis. Indian J Psychiatry 1998;40(2):149-57.

5. Murray CJ, Lopez AD. The global burden of disease: a comprehensive assessment of mortality and disability from diseases, injuries and risk factors in 1990 and projected to 2020. Cambridge MA: Harvard University Press, 1996.

6. The World Health Report. Mental health: New understanding, New Hope, 2001.

7. Goldberg JF, Harrow M, Grossman LS. Course and outcome in bipolar affective disorder: a follow-up study. Am J Psychiatry 1995;152:379-384.
8. Lewis L, Judd MD, Hagop S, et al. Psychosocial disability in the course of bipolar I and II disorders. Arch Gen Psychiatry 2005;62(12):1322-1330.

9. Dilsaver CC, Chen YW, Swann AC. Suicidality, panic disorder and psychosis in bipolar depression depressive mania and pure mania. Psychiatry Res 1997;73:47-56.

10. Bowden CL. Strategies to reduce misdiagnosis of bipolar depression. Psychiatr Serv 2001;52:51-55.

11. Chakrabarti S, Kulhara P, Verma SK. Extent and determinants of burden among families of patients with affective disorders. Acta Psychiatr Scand 1992;105:161162.

12. Indian psychiatric society. Indian disability evaluation and assessment scale (IDEAS). Annual national conference of Indian psychiatric society, Kolkata 2002.

13. Pai S, Kapur RL. The burden on the family of a psychiatric patient development of an interview schedule. $\mathrm{Br} \mathrm{J}$ Psychiatry 1981;138:322-335.

14. Fernando Kratz Gazalle, Ana Cristina. Bipolar depression: the importance of being on remission. Rev Bras Psiquiatr, Sao Paulo 2006;28(2).

15. Yatham LN, Lecrubier Y, Fieve RR. Quality of life in patients with unipolar I depression: data from 920 patients. Bipolar Disorder 2004;6:379-385.

16. Judd LL, Akiskal HS, Schettler PJ. The long-term natural history of the weekly symptomatic status of bipolar I disorder. Arch Gen Psychiatry 2002;59:530-537.

17. Judd LL, Akiskal HS, Schettler PJ. A prospective investigation of the natural history of the long-term weekly symptomatic status of bipolar II disorder. Arch Gen Psychiatry 2003;60:261-269.

18. Szmukles GI, Burgers P, Herman H. Caring of relatives with serious mental illness: the development of experience of care giving inventory. Soc Psych Epidem 1996;31:134-48.

19. Perlis RH, Miyahara S. Long term implication of early onset bipolar disorder data from the first 1000 participants in the systemic treatment enhancement programme for bipolar disorder. Biol Psychiatry 2004;55:875-881.

20. Mark Olfson, Bruce fireman, Myrna M. Mental disorders and disability among patients in a primary care group practice. Am J Psychiatry 1997;154:1734-1740.

21. Tucci, Adriana M, Kerr Correa. Social disability in patients with bipolar and unipolar affective disorder, dysthymia and double depression. Rev Bras Psiquiatr 2001;23(2):79-87.

22. Alison M, Christine E. Depressive symptoms and family functioning in the caregivers of recently hospitalized patients with chronic/recurrent mood disorders. The International Journal of Psychosocial Rehabilitation 7:5360 .

23. Chieko Hasui, Shinji Sakamoto, Tomko Sugiura. Burden on family members of the mentally ill: a naturalistic study in Japan. Comprehensive Psychiatry 2002;43(3):219-222.

24. Kim T, Carmen Webb, Margaret PF. Family burden of schizophrenia and bipolar disorder: perception of relatives and professionals. Psychiatric Services 1996;47(5):507-11.

25. Roychaudhuri J, Mondal D, Boral A. Family burden among long-term psychiatric patients. Indian J Psychiatry 1995;37(2):81-5. 